\title{
THE EFFECTIVENESS OF DIABETES SELF-MANAGEMENT EDUCATION PROGRAM IN IMPROVING SELF-CARE AMONG PATIENTS WITH TYPE 2 DIABETES MELLITUS
}

\author{
Ana Damayanti'1,2), Didik Tamtomo3), Dono Indarto4) \\ 1)Faculty of Health Science, Universitas Borneo, Tarakan, North Kalimantan \\ ${ }^{2}$ Masters Program in Public Health, Universitas Sebelas Maret \\ 3)Department of Anatomy, Faculty of Medicine, Universitas Sebelas Maret \\ 4)Department of Physiology, Faculty of Medicine, Universitas Sebelas Maret
}

\begin{abstract}
Background: Diabetes self-management education (DSME) is a critical element of care for all people with diabetes and those at risk for developing the disease. It is necessary in order to prevent or delay the complications of diabetes and has elements related to lifestyle changes that are also essential for individuals with prediabetes as part of efforts to prevent the disease. This study aimed to examine the effectiveness of diabetes self-management education program in improving selfcare among patients with type 2 diabetes mellitus.

Subjects and Method: A randomized controlled trial study was carried out in 7 puskesmas (community health centers) in Tarakan, North Kalimantan, from March 28 to May 20, 2018. A sample of 126 diabetes patients was selected for this study by simple random sampling, comprising 63 patients as intervention group and 63 patients as control group. The dependent variable was diabetes self-management behavior. The independent variables were diabetes self-management education program (DSME). The data were collected by questionnaire. The difference between two groups was analyzed by t-test.

Results: Self-management behavior in the DSME group (median= 26; $\mathrm{SD}=6.62$ ) was better than the control group (median $=21 ; \mathrm{SD}=4.55$ ) with $\mathrm{p}<0.001$.

Conclusion: Diabetes self-management education program is effective to improve self-management behaviour among patients with type 2 diabetes mellitus.

Keywords: diabetes self-management education, self-management behavior, type 2 diabetes mellitus patient

\section{Correspondence:}

Ana Damayanti. Masters Program in Public Health, Universitas Sebelas Maret, Jl. Ir. Sutami 36 A, Surakarta 57126, Central Java.

Email: damayanti.titha@gmail.com. Mobile: +6281347727774.
\end{abstract}

The 4th International Conference on Public Health

Best Western Premier Hotel, Solo, Indonesia, August 29-30, 2018 | 311 https://doi.org/10.26911/theicph.2018.05.25 